\title{
Review of Malcolm Rutherford's The institutionalist movement in American economics, 1918-1947: science and social control. Cambridge (UK): Cambridge University Press, 2011, 410pp.
}

\section{DAVID GINDIS}

University of Hertfordshire Business School

In publications spanning just over three decades, Malcolm Rutherford has been an important contributor to the study of American institutionalism as both a theoretical framework and an intellectual movement. His earlier research appraised the ideas of key figures of American institutionalism, namely Thorstein Veblen, John R. Commons, Wesley C. Mitchell, and Clarence Ayres. Following the rise of the so-called "new institutional economics" in the 1980s, associated with future Nobel laureates Ronald H. Coase, Douglass C. North, and Oliver E. Williamson, many of Rutherford's subsequent publications involved the comparative assessment of this "new" institutionalism and what had become by implication the "old". This line of inquiry gave us the earlier monograph, Institutions in economics: the old and the new institutionalism (Rutherford 1994).

For the last fifteen years or so, Rutherford's efforts have centered on developing a systematic study of American institutionalism in the interwar period, thereby meeting the challenge spelled out in his Presidential address to the History of Economics Society (Rutherford 1997). The result, based on meticulous archival labor, is this goldmine of a book. Although much of the material Rutherford invites us to consider has been previously published in a series of journal articles, this book, published in the "Historical Perspectives on Modern Economics" series edited by Craufurd D. Goodwin, brings together what we had only seen glimpses of in a well-written and tightly-knit narrative. ${ }^{1}$ This is the definitive history of American institutionalism, and surely the benchmark for any research to come.

Like previous book-length accounts of American institutionalism (Yonay 1998; Hodgson 2004), part one ("Introduction") of Rutherford's book demonstrates that institutionalism was anything but the somewhat

\footnotetext{
${ }^{1}$ A précis can be found in the Autumn 2010 issue of this journal (Rutherford 2010).
} 
juvenile, anti-theoretical dissent from neoclassicism that later critics such as George J. Stigler and others depicted it to have been. Contrary to this "standard view", to which Coase and Williamson also subscribe, Rutherford's "revisionist view" (p. 5ff.) stems from the observation that institutionalism in the interwar period cannot be characterized simply as dissent against neoclassicism since neoclassicism's rise to dominance in American academia coincided with the rise of Keynesianism, that is, mainly after World War II.

In the period under consideration, American economics was pluralistic in terms of the variety of ideologies, methods, and policy prescriptions (see also Morgan and Rutherford 1998). Institutionalists published in leading journals, held positions in major research universities, served as presidents of major scientific associations, were active in the creation of research and educational organizations, were recipients of substantial funds from all the important researchsponsoring foundations, and were heavily involved in policy making, particularly during the New Deal. Institutionalism, in other words, was part of the mainstream.

Institutionalism, however, was not a well-defined "school" of economic thought but was rather what Rutherford calls a "movement", that is, a network of people who actively promoted the development of an "institutional approach" to economics in line with Walton H. Hamilton's foundational institutionalist manifesto, presented at a special session of the American Economic Association meetings in 1918 (Hamilton 1919). Rutherford's argument is that the group of explicitly self-identified members of the institutionalist movement, led by Hamilton, Mitchell, and John M. Clark, were held together by a common conception of "science" and the desire to use science as an instrument of "social control" (chapter 2).

In a nutshell, the institutionalists were critical of the abstract theorizing associated with neoclassical economics, and rejected the universal depiction of man as a "lightning calculator of pleasures and pains", to use Veblen's celebrated expression. They believed that economic theory had to be based on assumptions that conform to realworld conditions, and took this to require not only a strong empirical, investigative and problem-centered approach but also a strong degree of consistency with scientific knowledge in contiguous fields, such as psychology, sociology, and law (p. 8). Without these features, they argued, economic theory would never be scientific and relevant to 
the pressing social problems of the day (e.g., labor unrest, business cycles, unemployment, poverty, externalities, monopoly, and so forth).

Hence, while Veblen's concepts and concerns, such as his stress on pecuniary institutions, were retained by institutionalists, they generally did not adopt Veblen's evolutionary approach, viewing it as ill-suited for deliberative social guidance and legislative reform (pp. 38-39). In consonance with the earlier generation of American progressive economists-particularly Richard T. Ely and Henry C. Adams-the institutionalists were pragmatists of Deweyan persuasion, emphasizing reform through legislative and legal change, and many of them, including Hamilton, Clark, Commons, and Robert Lee Hale, had close connections with the legal realist movement that similarly rejected abstract jurisprudence and advocated an empirically-grounded legal science (see also White 1976 [1949]; and Schlegel 1995).

Rutherford's argument is skillfully substantiated in the most detailed analysis to date of the writings, projects, and careers of all the self-proclaimed institutionalists. In part two ("Institutionalist careers") Rutherford concentrates on Hamilton (chapter 3), the chief promoter of the institutional approach, and illustrates Hamilton's influence by offering a rare discussion of Morris A. Copeland, a conspicuous representative of the second generation of institutionalists who worked in both academia and government after studying under Hamilton, Clark, and others (chapter 4).

The narrative goes on to present the network of people, research programs and curricula to be found in the hauts lieux of interwar institutionalism in part three ("Centers of institutional economics"). Rutherford supplies helpful tables of selected faculty and graduate students at each of these centers, allowing us to get a real sense of the mobility within the network by following the trails of individual careers. Rutherford begins with the University of Chicago that under Veblen's influence was undeniably pivotal in the formation and early history of the institutionalist movement prior to 1918 (chapter 5). Rutherford then guides us through Hamilton's two main educational experiments, Amherst College in Massachusetts and the Brookings Graduate School in Washington D.C., which produced many members of the second generation, including Copeland (chapter 6).

Our attention is next directed to the University of Wisconsin where, following the path broken by Ely, Commons and his numerous students developed a distinct variety of institutionalism (chapter 7). 
From Wisconsin we turn to the other major institutionalist stronghold, Columbia University in New York, then one of America's top $\mathrm{PhD}$ granting universities, where the institutionalist cohort included Mitchell, Clark, John Dewey, Adolf A. Berle, and Gardiner C. Means (chapter 8). Finally, we learn of the vital links between institutionalists and key executives of the Carnegie and Rockefeller Foundations who, based on a remarkable convergence of beliefs about science and social control, backed the creation in 1920 of the National Bureau of Economic Research (NBER) in New York, where Mitchell and many others engaged in ground-breaking statistical research on business cycles (chapter 9).

The oft-debated factors contributing to the decline of American institutionalism in the post-1945 period are discussed in part four ("Challenges and changes"). Although institutionalism cannot be properly characterized as merely dissent against neoclassicism in the interwar period, after World War II it certainly did become a dissenting heterodoxy lying outside of the mainstream of American economics that became dominated by both neoclassical and Keynesian economics. Rutherford argues that the relationship between institutionalism and what became Keynesian economics is more complex than is usually acknowledged (chapter 10), ${ }^{2}$ much more complex, in any case, than the view that institutionalists were left helpless by the Great Depression and fell victim to its Keynesian remedy (e.g., Ross 1991, 419).

As Rutherford explains, the institutionalists' interest in underconsumption goes back to Veblen. In the 1930s many of them, particularly Clark at Columbia, Mitchell at the NBER, and Rexford G. Tugwell (a prominent member of President Franklin D. Roosevelt's original "Brains Trust") in government, were explicitly proposing counter-cyclical public expenditures to deal with unemployment (p. 292ff.). Indeed, Mitchell and others viewed their empirical work on cycles of various sorts as informing decisions of this kind. A few institutionalists converted partly or wholly to Keynesian economics, but many others, in particular Mitchell, Clark, and Copeland, remained highly critical of Keynesian macroeconomics and the associated new econometric modeling, repeatedly underlining the factors omitted in the models and the "Ricardian vice" involved. This apprehension, however, was not shared by the new post-1945 generations of economists. Keynesianism offered them the possibility of social control based on the latest and most scientific approach to economics.

\footnotetext{
${ }^{2}$ This chapter is based on an article co-authored by Tyler DesRoches.
} 
By the end of what G. L. S. Shackle (1967) called the "years of high theory", the neoclassical economist's toolbox had significantly expanded from its Marshallian foundations, posing a serious challenge to institutionalism (chapter 11). When combined with Arthur C. Pigou's analysis of externalities and social costs, the pioneering work on imperfect competition by Edward H. Chamberlin and Joan Robinson allowed neoclassical economists to address questions that were previously in the institutionalists' domain. In the meantime, key developments in utility theory, associated with John R. Hicks and Paul A. Samuelson, began to slowly but irreversibly separate economic theory from psychology (pp. 316-317). By the time of Samuelson's (1947) Foundations of economic analysis, the institutionalists' concern with realistic assumptions was increasingly ignored by neoclassical economists, and within years Milton Friedman's positivist defense of an "as if" methodology of model-building seemed to have settled the matter for the profession.

Rutherford's explanation of the relatively rapid decline of American institutionalism during what Mark Blaug (2003) described as the "formalist revolution" hinges on the same elements that allowed him to define institutionalism as a movement and to document its internal dynamics between the wars. Important changes in the American academic environment transformed the standards of scientific economics, weakening the movement's claim to science. The institutionalists' general reluctance to embrace the new econometric modeling techniques led to the lasting, albeit misleading, reputation of institutionalism as "measurement without theory" (Koopmans 1947). As mainstream economics became increasingly separated from psychology, sociology, and law, institutionalism's interdisciplinary orientation lost its appeal. In this context, the institutionalist network could no longer retain its position at the pinnacles of American education and research. America's top universities stopped hiring institutionalists, and the movement grew smaller and more scattered, both geographically and in terms of social cohesion, until it became marginalized within the profession (pp. 340-341).

There is much to commend in this book. It performs a great service to the community of historians of American economics, who will relish the details of the flow of people and ideas within the institutionalists' network during the interwar period, assembled here thanks to many years of painstaking efforts in the archives. Readers with an interest in 
institutional economics will appreciate that caricatures of American institutionalism as anti-theoretical dissent fail to come to terms with the historical facts, and learn from Rutherford's disagreements with Hodgson (2004) regarding the relative importance of Veblen's evolutionary economics for interwar institutionalism (p. 349), and their contrasting interpretations of Frank H. Knight's position (p. 146). Finally, readers with a methodology background will welcome Rutherford's discussions of the institutionalists' views of science and scientific methods, and his illustration that in economics, as in other disciplines, changes in what is widely perceived as normal science may help paradigms rise but also ensure their fall.

Rutherford's book also raises a number of questions that future research will need to address. An important issue that fits well with the definition of institutionalism as a movement concerned with science and social control is the matter of the institutionalists' ontological commitments. I suspect that the institutionalists' social ontology can be partially revealed by an examination of their engagement with the corporate personality controversy that dominated the legal literature between roughly 1900 and 1930 (Gindis 2009). Rutherford mentions the controversy only in passing, mainly in connection with Dewey's dismissive remarks (p. 244), and with Hamilton's later disapproval of legal fictions as barriers to the domestication of the "corporate ghost" (p. 92). Given that other members of the institutionalist network, particularly Commons and the British political scientist Harold Laski, were concerned with the nature of corporate personality, and by extension with the nature of corporations and human associations more generally, the connection deserves further investigation.

\section{REFERENCES}

Blaug, Mark. 2003. The formalist revolution of the 1950s. In A companion to the history of economic thought, eds. Warren J. Samuels, Jeff E. Biddle, and John B. Davis. Oxford: Blackwell, 395-410.

Gindis, David. 2009. From fictions and aggregates to real entities in the theory of the firm. Journal of Institutional Economics, 5 (1): 25-46.

Hamilton, Walton H. 1919. The institutional approach to economic theory. American Economic Review, 9 (1): 309-318.

Hodgson, Geoffrey M. 2004. On the evolution of institutional economics: agency, structure and Darwinism in American institutionalism. London: Routledge.

Koopmans, Tjalling C. 1947. Measurement without theory. Review of Economic Statistics, 29 (3): 161-172. 
Morgan, Mary S., and Malcolm Rutherford. 1998. American economics: the character of the transformation. History of Political Economy, 30 (1): 1-26.

Ross, Dorothy. 1991. The origins of American social science. Cambridge: Cambridge University Press.

Rutherford, Malcolm. 1994. Institutions in economics: the old and the new institutionalism. Cambridge: Cambridge University Press.

Rutherford, Malcolm. 1997. American institutionalism and the history of economics. Journal of the History of Economic Thought, 19 (2): 178-195.

Rutherford, Malcolm. 2010. Science and social control: the institutionalist movement in American economics, 1918-1947. Erasmus Journal for Philosophy and Economics, 3 (2): 47-71.

Samuelson, Paul A. 1947. Foundations of economic analysis. Cambridge (MA): Harvard University Press.

Schlegel, John H. 1995. American legal realism and empirical social science. Chapel Hill (NC): University of North Carolina Press.

Shackle, George L. S. 1967. The years of high theory: invention and tradition in economic thought, 1926-1939. Cambridge: Cambridge University Press.

White, Morton G. 1976 [1949]. Social thought in America: the revolt against formalism. New York: Oxford University Press.

Yonay, Yuval. 1998. The struggle over the soul of economics: institutionalist and neoclassical economists in America between the wars. Princeton (NJ): Princeton University Press.

David Gindis is lecturer of economics at the University of Hertfordshire Business School (UK), where he is a member of the Group for Research in Organizational Evolution (GROE). His research interests include institutional economics, evolutionary economics, law and economics, economic methodology, and social ontology. His specific focus is on the institutional aspects of the emergence, persistence, and evolution of firms in market economies. In 2008 he was awarded the Herbert Simon Young Scholar Prize by the European Association for Evolutionary Political Economy (EAEPE).

Contact e-mail: <d.gindis@herts.ac.uk> 